\title{
Spatial and temporal bacterioplankton dynamics during destratification of the James River estuary, Virginia, USA
}

\author{
Eric T. Koepfler*, Howard I. Kator, Richard L. Wetzel, Leonard W. Haas, \\ Kenneth L. Webb
}

Virginia Institute of Marine Science, College of William and Mary, Gloucester Pt., Virginia 23062, USA

\begin{abstract}
Bacterioplankton abundance and production were examined over the course of a destratification event in the lower James River, Virginia, USA. Goals of the study were to determine if destratification would influence temporal patterns of bacterioplankton parameters and relationships between bacterioplankton and other biological and abiological parameters. Mean bacterial abundance grouped over stations did not change over the course of the study, and were characterized by much smaller coefficients of variation than all other planktonic constituents. However, bacterial production measured by ${ }^{3} \mathrm{H}$-thymidine $\left({ }^{3} \mathrm{H}\right.$-Tdr) incorporation decreased significantly from a stratified $\left(324 \mu \mathrm{g} \mathrm{C}^{-1} \mathrm{~d}^{-1}\right)$ to a destratified (187 $\mathrm{g} \mathrm{C} \mathrm{C}^{-1} \mathrm{~d}^{-1}$ ) hydrography. The importance of bacterial-autotrophic coupling was also suggested from oxygen metabolism experiments, which indicated substrate limitation of bacteria, and the existence of a rapidly utilized photosynthetically produced substrate. Correlative relationships between bacterial parameters with chlorophyll a were significant during stratified hydrography, but diminished or became non-significant during destratified hydrography. Estimates of microzooplankton grazing rates upon bacteria decreased significantly during the onset of destratification. During the stratified hydrography, bacterial parameters displayed highly significant negative correlations to ammonium, however these relationships disappeared during the destratified hydrography. Results of this study indicate that destratification changes the trophic interactions of bacteria within the microbial loop, however these changes are not necessarily reflected by temporal patterns of bacterial abundance.
\end{abstract}

KEY WORDS: Bacterioplankton - Heterotrophic flagellates - Hydrography - Nutrients - Substrate Thymidine incorporation

\section{INTRODUCTION}

Knowledge concerning the importance of bacterioplankton in microbial food webs has accrued rapidly since the seminal theoretical works of Williams (1981) and Azam et al. (1983). Studies of bacterioplankton production and distribution in estuaries and coastal areas provide evidence that bacteria greatly influence carbon cycling processes by assimilating photosynthetically produced dissolved organic matter (Chróst \& Faust 1983, Iturriaga \& Zsolnay 1983, Gomes et al.

\footnotetext{
- Present address: Marine Science Department, Coastal Carolina University, Conway, South Carolina 29526, USA
}

1991), and by serving as an important food resource for heterotrophic flagellates and ciliates (e.g. Sherr \& Sherr 1977, Haas \& Webb 1979, Fenchel 1982, Wright \& Coffin 1983a, b, 1984). Work by Ducklow \& Peele (1987) has emphasized the importance of bacteria in estuaries, showing that bacterial production and biomass may exceed those of autotrophic assemblages for extended periods in the Chesapeake Bay, USA. Although it is generally accepted that substrate availability and grazing affect estuarine bacterioplankton activity and populations, little is known regarding the influence of estuarine hydrography upon these processes.

Estuaries provide convenient locations to examine the influence of changing hydrography upon bacterio- 


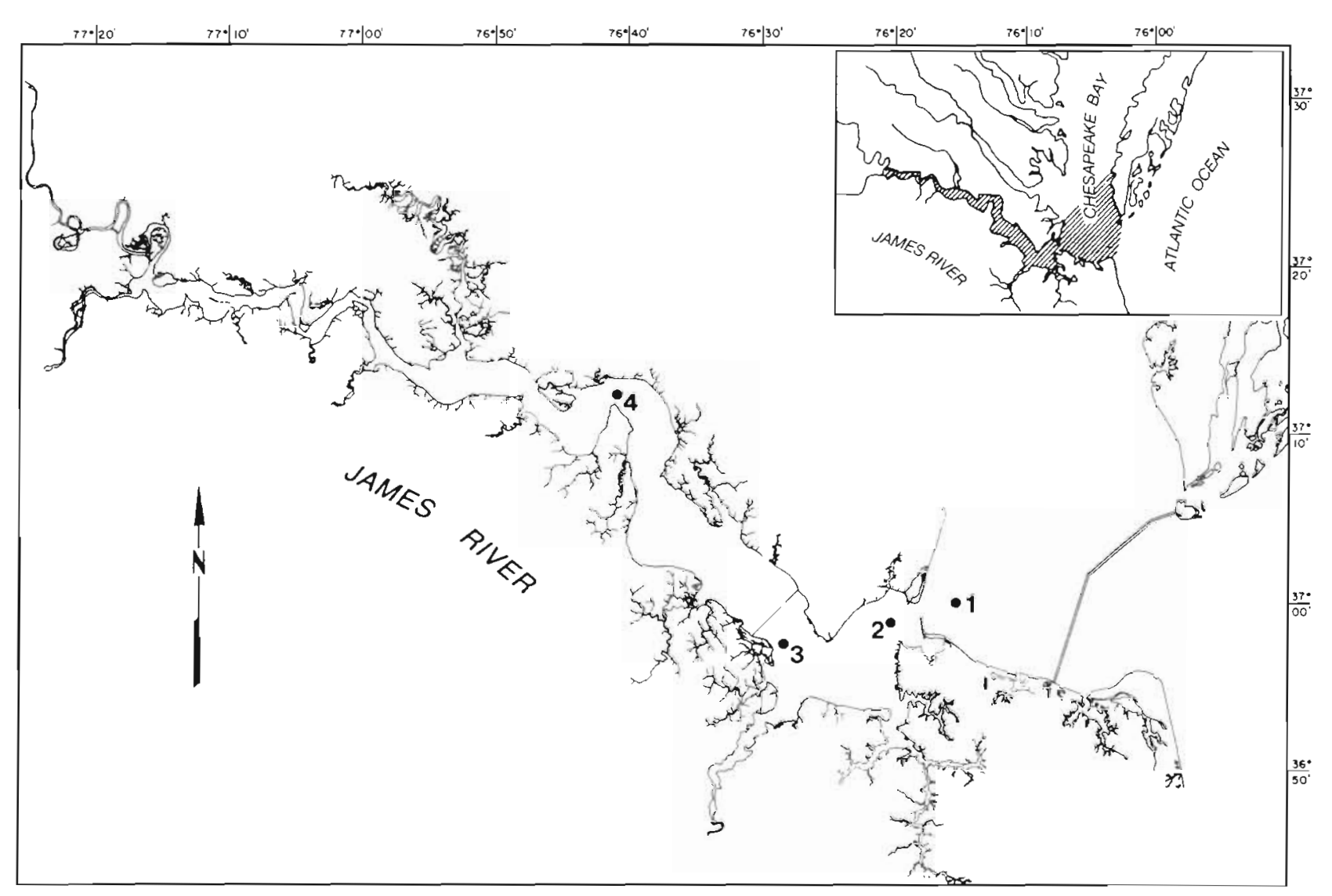

Fig. 1. Location of stations in the James River Estuary, Virginia, USA

plankton growth and trophic interactions. Haas (1977) demonstrated that portions of lower Chesapeake Bay subestuaries oscillate between moderately stratified and vertically homogenous conditions on time scales as brief as days. Destratification in the York River estuary, Virginia, USA, has been shown to redistribute ammonium- and phosphate-rich bottom water as well as more highly oxygenated surface water throughout the water column (Webb \& D'Elia 1980). Mixing processes may also result from less extreme hydrographic changes, such as wind-driven pycnocline oscillations (Malone et al. 1986). The immediate effects of water column mixing upon various microbial components are not well known or predictable. Although phytoplankton blooms (Haas et al. 1981) and the stimulation of bacterial production (Ducklow 1982) have been reported coincident with destratified hydrography, other studies have indicated that these processes are depressed under such conditions and are enhanced only when stratification reoccurs (Malone et al. 1986, Ray et al. 1988).

Prior to this study, Ducklow (1982) had reported that destratification in the York River estuary resulted in increased bacterial abundance and production rates.
Based upon this information, we hypothesized that a similar response would be observed during destratification in the neighboring James River estuary. Objectives of this study were to examine the influence of destratification upon (1) bacterial production and abundance, and (2) the relationships between bacterial and biological and abiological variables. Data were also examined to determine the degree of spatial and temporal variability of study parameters, and to determine overall relationships between bacterioplankton and ancillary parameters.

\section{METHODS AND MATERIALS}

Study area and sampling. Samples were collected at 4 stations on 6 dates from the RV 'Ridgely Warfield' (Johns Hopkins University). Station locations (Fig. 1) ranged from Stn 1, located $6 \mathrm{~km}$ outside the mouth of the James River, to Stn 4,54 km upriver from the river mouth. Sampling of surface, pycnocline and bottom waters were performed on $6,9 \& 12$ August 1983. Additional surface water samples were taken on 8,10 \& 12 August 1983. On dates when depth profile samples 
Table 1. Methodologies utilized for determination of ancillary parameters

\begin{tabular}{|ll|}
\hline \multicolumn{1}{|c|}{ Parameters } & \multicolumn{1}{c}{ Source } \\
\hline $\begin{array}{l}\text { Whole and }<15 \mu \mathrm{m} \mathrm{chl} a \text {, and phaeopigment ratio } \\
\text { Abundances of cyanobacteria, microflagellates, dinoflagellates, } \\
\text { diatoms and heterotrophic flagellates }\end{array}$ & $\begin{array}{l}\text { Holm-Hansen (1966), Ray et al. (1988) } \\
\text { Haas (1982) }\end{array}$ \\
$\begin{array}{l}\text { Nutrients; ammonium, nitrite, nitrate, silicate and phosphate } \\
\text { Particulate organic carbon and nitrogen }\end{array}$ & U.S. Environmental Protection Agency (1979) \\
$\begin{array}{l}\text { Relative dissolved organic matter } \\
\text { Salinity, temperature and conductivity }\end{array}$ & Patterson (1973) \\
Dissolved oxygen & Foster \& Morris (1974) \\
\end{tabular}

were taken, preliminary hydrographic information was obtained using a Neil-Brown CTD to determine the appropriate depth for sampling of the pycnocline. Surface $(0.5 \mathrm{~m})$, pycnocline and bottom water (ca $1 \mathrm{~m}$ above sediment) samples were then collected with a $5 \mathrm{l}$ Niskin bottle which was washed with $95 \%$ ethanol and rinsed with distilled water between casts. Stations were sampled whenever possible at low slack water.

Bacterioplankton abundance and production. Bacterial abundance was estimated via an epifluorescence direct-counting technique using the dye proflavine (Haas 1982). Cells were counted using a Zeiss standard microscope equipped with a $50 \mathrm{~W}$ high-pressure mercury lamp, $10 \times$ calibrated ocular, $100 \times$ Neofluar $^{\circ}$ or $63 \times$ Plan apo (Carl Zeiss, New York, NY, USA) objectives. Bacterioplankton biomass was estimated using a $20 \times 10^{-15} \mathrm{~g} \mathrm{C} \mathrm{cell}^{-1}$ conversion value (Lee \& Fuhrman 1987). Total coccoid cyanobacteria were enumerated using a blue excitation (450 to $490 \mathrm{~nm}$; Zeiss \#487709) epifluorescence filter set for counting phycoerythrincontaining cells, and a green excitation $(510$ to $560 \mathrm{~nm}$; Zeiss \#487714) filter set which enabled counting of phycocyanin-containing cells.

Bacterial production was estimated using tritiated thymidine ( ${ }^{3} \mathrm{H}-\mathrm{Tdr}$ ) (Fuhrman \& Azam 1980, 1982). Triplicate (pseudoreplicate) $10 \mathrm{ml}$ water samples were incubated with $5 \mathrm{nM}$ of ${ }^{3} \mathrm{H}-\mathrm{Tdr}\left(62 \mathrm{Ci} \mathrm{mmol}^{-1}\right)$ for $30 \mathrm{~min}$ in the dark at in situ temperatures. Triplicate killed control samples (300 $\mu \mathrm{l}$ of buffered formalin) were treated in a similar manner. Incubations were terminated with $300 \mu \mathrm{l}$ of buffered formalin and samples were stored at $4{ }^{\circ} \mathrm{C}$ prior to further processing within $48 \mathrm{~h}$.

Samples were prepared for radioassay by extraction with ice-cold $5 \%$ trichloroacetic acid (TCA), filtering onto $0.45 \mu \mathrm{m}$ Gelman GN-6 membrane filters and washing with 5 to $6 \mathrm{ml}$ of ice cold $5 \%$ TCA. Filters were transferred to scintillation vials and acid hydrolyzed for $30 \mathrm{~min}$ with $0.5 \mathrm{ml}$ of $0.5 \mathrm{~N} \mathrm{HCl}$ in a boiling water bath. After cooling, filters were dissolved with $1 \mathrm{ml}$ of ethyl acetate and $10 \mathrm{ml}$ of Aquasol $^{\circledast}$ scin- tillation cocktail. Disintegrations per minute were determined using a Beckman ${ }^{\circledR}$ scintillation counter, correcting for counting efficiency using an external standard channels and standard quench curve. Bacterial cell production was calculated using the conversion factor of $1.7 \times 10^{18}$ cells $\mathrm{mol}^{-1}{ }^{3} \mathrm{H}$-Tdr (Fuhrman \& Azam 1982). Carbon production was estimated assuming $20 \times 10^{-15} \mathrm{~g} \mathrm{C} \mathrm{cell}^{-1}$ (Lee \& Fuhrman 1987).

Ancillary parameters. Ancillary parameters were measured using the methods listed in Table 1. Multiple citations are listed for a parameter where methodological refinements described in later citations were also employed. Autotrophic biomass was estimated from

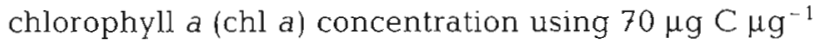
chl a (Malone et al. 1988).

\section{RESULTS}

Using a difference in surface-to-bottom salinity of less than 1 ppt to designate the destratified state (Ducklow 1982), hydrographic and physical data (Table 2) indicated that destratification occurred at Stms 2 through 4 on or about 9 August, the date of maximum spring tide. Differences between surface and bottom salinities, conductivities and temperatures were greater at each station on 6 August compared with 9 August. By 12 August, Stns 2 through 4 could be characterized as approaching a restratified state. Stn 1 remained in a stratified state throughout the duration of the study, yet displayed a progressive weakening in the vertical density gradient.

Mean coefficients of variation (CVs) of bacterial and ancillary data grouped by date, station and depth (Table 3) indicated that parameter variability was generally greater on spatial than on temporal scales. Bacterial abundance was less variable, regardless of grouping, compared with other plankton components. Bacterial abundance and production as well as diatoms, chl a and phaeopigment ratios were most variable over depth. Nutrient concentrations and 
Table 2. Values of surface minus bottom hydrographic data obtained from depth profile sampling dates. $Z$; depth $(\mathrm{m})$; $S$ : salinity (ppt); $C$ : conductivity (mmho $\mathrm{cm}^{-1}$ ); $T$ : temperature, $O$ : oxygen concentration (ppm). ns: not sampled

\begin{tabular}{|c|c|c|c|c|}
\hline Stn & & 6 August & 9 August & 12 August \\
\hline \multirow[t]{5}{*}{1} & $Z$ & 17.9 & 23.0 & 20.6 \\
\hline & $S$ & 7.65 & 4.72 & 3.47 \\
\hline & $C$ & 7.48 & 3.47 & 3.39 \\
\hline & $T$ & 6.21 & 3.97 & 3.09 \\
\hline & $O$ & 1.20 & 1.06 & 1.20 \\
\hline \multirow[t]{5}{*}{2} & $Z$ & 13.0 & 14.0 & 13.6 \\
\hline & $S$ & 3.61 & 0.06 & 0.15 \\
\hline & $C$ & 3.48 & 0.08 & 0.27 \\
\hline & $T$ & 3.17 & 0.15 & 0.52 \\
\hline & $O$ & 1.60 & 0.50 & 0.70 \\
\hline \multirow[t]{5}{*}{3} & $Z$ & 6.0 & 5.6 & 6.0 \\
\hline & $S$ & 3.13 & 0.81 & 0.99 \\
\hline & $C$ & 2.74 & 0.87 & 0.80 \\
\hline & $T$ & 1.22 & 0.81 & 0.19 \\
\hline & 0 & 0.08 & 1.36 & 0.70 \\
\hline \multirow[t]{5}{*}{4} & $Z$ & 6.2 & 7.9 & 7.0 \\
\hline & $S$ & 1.06 & 0.33 & 0.91 \\
\hline & $C$ & 0.73 & ns & 0.66 \\
\hline & $T$ & 0.25 & 0.02 & 0.33 \\
\hline & $O$ & 0.94 & 1.20 & 0.20 \\
\hline
\end{tabular}

abundance of autotrophic taxa varied most when grouped by station. Only dissolved oxygen and cyanobacterial abundance displayed greater temporal than spatial variability.

Bacterial abundance ranged from 3.1 to $12.6 \times 10^{6}$ cells $\mathrm{ml}^{-1}$, similar to values reported by Malone et al. (1986) for a study site in the upper Chesapeake Bay, and slightly higher than the range of values reported by Ducklow (1982) for the York River (1.0 to $8.0 \times 10^{6}$ cells $\left.\mathrm{ml}^{-1}\right)$. Bacterial production ranged from 74 to $426 \mu \mathrm{g} \mathrm{C}^{-1} \mathrm{~d}^{-1}$, similar to values reported by Malone et al. (1986) for the mid-Chesapeake Bay, and somewhat higher than values reported for the Delaware Bay estuary, USA (Wright \& Coffin 1984, Coffin \& Sharp 1987). Bacterial production and abundance decreased significantly with depth (1-tailed $t$-test; $\mathrm{p}=0.033$ and $\mathrm{p}=0.0005$ respectively). Bacterial production de-

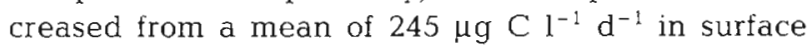

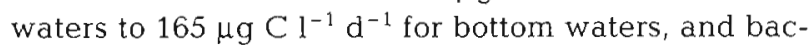
terial abundance decreased from $9.3 \times 10^{6} \mathrm{cells} \mathrm{m}^{-1}$ in surface waters to $6.5 \times 10^{6}$ cells $\mathrm{ml}^{-1}$ in bottom waters. Spatial trends in surface and pycnocline waters (Fig. 2a, b, e, f) suggested that abundance and production were higher in the lower estuary compared to the upper estuary. Means of bacterial abundance (Fig. 2e)

Table 3. Descriptive statistics of study parameters. Values include range, mean, and mean coefficient of variation (CV') based upon data groupings of the entire data set and date, station and depth categories. $C V^{\prime}$ was calculated as $\Sigma_{i j}\left(C V_{k}\right) /(i j)$ where $k$ is the CV grouping of concern (i.e. depth), and $i$ and $j$ are alternative groupings (station and date) such that $C V^{\prime}$ would be the mean of $i(=4) \times j(=3)=12$ station-date combinations. $C V^{\prime}$ for entire category indicates coefficient of the entire data set

\begin{tabular}{|c|c|c|c|c|c|c|c|}
\hline \multirow[t]{2}{*}{ Parameter } & \multirow[t]{2}{*}{ Units } & \multirow[t]{2}{*}{ Range } & \multirow[t]{2}{*}{ Mean } & \multicolumn{4}{|c|}{ Coefficient of variation $\left(\mathrm{CV}^{\prime}\right)$} \\
\hline & & & & Entire & Date & Station & Depth \\
\hline Bacterial production (PD) & $\mu g \mathrm{Cl}^{-1} \mathrm{~d}^{-1}$ & $74-426$ & 205 & 45.6 & 38.1 & 44.5 & $44.9^{\mathrm{b}}$ \\
\hline Bacterial abundance (LBA) & $\log \left(\mathrm{ml}^{-1}\right)$ & $6.50-7.10$ & 6.90 & 1.52 & 0.90 & $1.2 \hat{6}$ & $1.36^{\mathrm{b}}$ \\
\hline $\begin{array}{l}\text { Heterotrophic flagellate } \\
\text { abundance (LHNAN) }\end{array}$ & $\log \left(m l^{-1}\right)$ & $2.33-3.81$ & 3.52 & 7.53 & 3.36 & $4.89^{\mathrm{b}}$ & 3.57 \\
\hline Cyanobacteria abundance (LCY) & $\log \left(\mathrm{ml}^{-1}\right)$ & $4.32-6.11$ & 5.48 & 7.23 & $6.21^{\mathrm{b}}$ & 4.62 & 4.36 \\
\hline Diatom abundance (LDI) & $\log \left(\mathrm{ml}^{-1}\right)$ & $2.82-3.98$ & 3.49 & 9.17 & 4.42 & 7.67 & $7.75^{b}$ \\
\hline Dinoflagellate abundance (LDN) & $\log \left(\mathrm{ml}^{-1}\right)$ & $0.00-3.17$ & 1.80 & 61.4 & 75.4 & $90.9^{b}$ & 82.3 \\
\hline Microflagellate abundance (LUF) & $\mu \mathrm{gchl} \mathrm{l}^{-1}$ & $2.80-3.82$ & 3.32 & 8.80 & 6.68 & $8.40^{\mathrm{b}}$ & 6.52 \\
\hline Total chl a (TCHL) & $\mu g \operatorname{chl} 1^{-1}$ & $5.86-17.4$ & 11.3 & 27.8 & 19.0 & 18.2 & $28.8^{b}$ \\
\hline$<15 \mu \mathrm{m}$ chlorophyll (SCHL) & $\mu g \operatorname{chI} 1^{-1}$ & $4.35-14.2$ & 8.30 & 29.9 & 19.7 & 26.7 & $30.4^{b}$ \\
\hline Total phaeopigment ratio (PHA) & unitless & $1.26-1.67$ & 1.50 & 7.27 & 4.66 & 6.11 & $6.49^{\mathrm{b}}$ \\
\hline$<15 \mu \mathrm{m}$ phaeopigment ratio (SPHA) & unitless & $1.28-1.68$ & 1.49 & 5.84 & 2.94 & 3.96 & $5.20^{\mathrm{b}}$ \\
\hline Ammonium concentration (NH4) & $\mu \mathrm{mol} \mathrm{l} \mathrm{l}^{-1}$ & $0.00-7.68$ & 2.40 & 84.3 & 57.3 & $71.1^{\mathrm{b}}$ & 49.7 \\
\hline Nitrite concentration (NO2) & $\mu \mathrm{mol} \mathrm{l} \mathrm{l}^{-1}$ & $0.18-3.80$ & 1.09 & 84.8 & 36.0 & $77.8^{\mathrm{b}}$ & 24.1 \\
\hline Nitrate concentration (NO3) & $\mu \mathrm{mol} \mathrm{I}^{-1}$ & $0.03-3.71$ & 1.16 & 91.8 & 47.1 & $97.1^{b}$ & 24.1 \\
\hline Phosphate concentration (PO4) & $\mu \mathrm{mol} \mathrm{l}^{-1}$ & $0.48-3.02$ & 1.47 & 41.7 & 27.6 & $37.5^{b}$ & 11.4 \\
\hline Silica concentration (SI) & $\mu \mathrm{mol} \mathrm{l} \mathrm{l}^{-1}$ & $17.1-57.2$ & 37.6 & 30.4 & 11.1 & $32.6^{\mathrm{b}}$ & 8.40 \\
\hline Particulate organic carbon (POC) & $\operatorname{\mu g} 1^{-1}$ & $326-5556$ & 1455 & 61.8 & 39.7 & $54.6^{\mathrm{b}}$ & 34.3 \\
\hline Particulate organic nitrogen (PON) & $\mu \mathrm{gl}^{-1}$ & $82-424$ & 189 & 34.6 & 11.8 & $37.0^{\mathrm{b}}$ & 24.1 \\
\hline DOM-salinity residual (SR) ${ }^{a}$ & ppt & $4.76-26.9$ & 15.0 & 44.9 & 6.84 & $50.8^{b}$ & 11.3 \\
\hline Dissolved oxygen (DO) & $\operatorname{mg} 1^{-1}$ & $5.36-8.46$ & 6.83 & 11.9 & $12.3^{b}$ & 6.72 & 7.97 \\
\hline
\end{tabular}



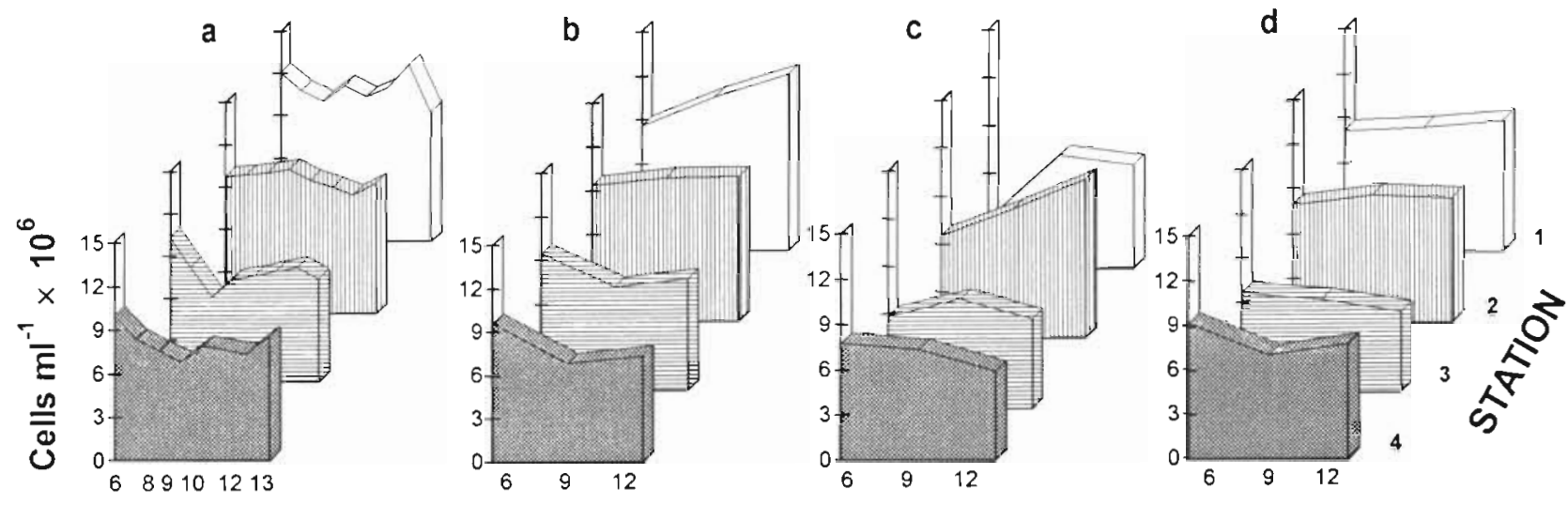

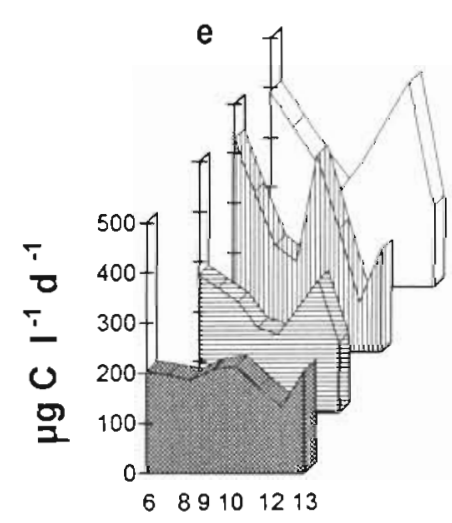

AUGUST

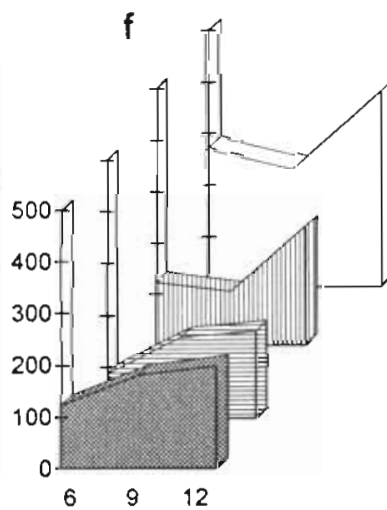

AUGUST

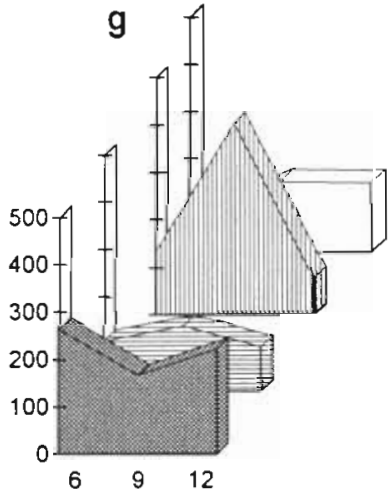

AUGUST

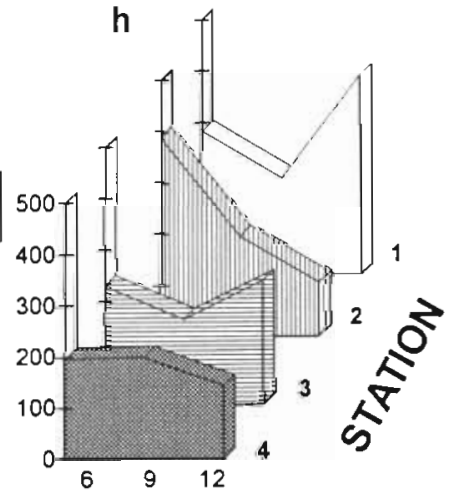

AUGUST

Fig. 2. Mean bacterial abundance and production by station and date for ( $a$, e) surface, (b, f) pycnocline and (c, $g$ ) bottom waters, and $(d, h)$ hypsometrically integrated water columns

initially displayed a gradation from low values at Stn 1 to higher values up-estuary. By 12 August this pattern had reversed with low bacterial abundance observed at Stn 4 grading to higher abundance down-estuary. Temporal variability of production was greater at Stns 1 \& 2 than Stns 3 \& 4. Production decreased between 6 and 9 August at Stns 1 through 3, but remained unchanged at Stn 4 (Fig. 2h). Integrated means of bacterial parameters (Fig. 2d, h) were calculated using station hypsometries. Means calculated in this manner were considered more accurate than simply averaging values from surface, pycnocline and bottom waters, as the volumes of water at these depths were markedly different.

Chl $a<15 \mu \mathrm{m}$ constituted on average $75 \%$ of total chlorophyll standing stock. Temporal variation in surface water chl a concentrations was greater at Stns 1, 2 \& 3 than Stn 4 (Fig. 3). Mean values of total chlorophyll in surface waters grouped over stations were lowest on 10 August, the day after maximum spring tides. Mean values of total and $<15 \mu \mathrm{m}$ phaeopigment ratios, particulate organic carbon and $\mathrm{C}$ to $\mathrm{N}$ ratios of particulate organic matter (data not shown) all exhibited maxi- mum values on 9 August. Hypsometric means of dissolved nutrients displayed strong spatial and tempora] patterns (Fig. 4a to e). Ammonium, nitrate, total dissolved nitrogen and phosphate concentrations exhibited high values at Stn 3, and generally lowest values at Stn 1. Nitrite concentrations ranged from low values

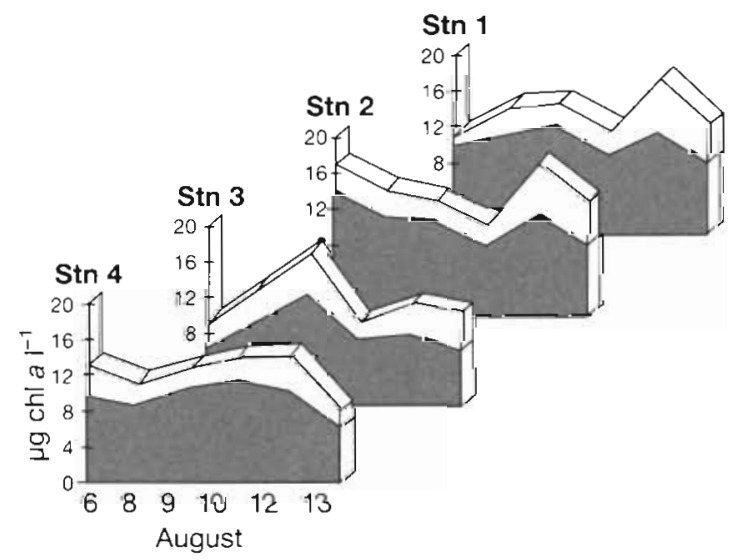

Fig. 3. Mean concentration of total chl a (clear) and $<15 \mu \mathrm{m}$ chl a (shaded) by station and date for surface water samples 

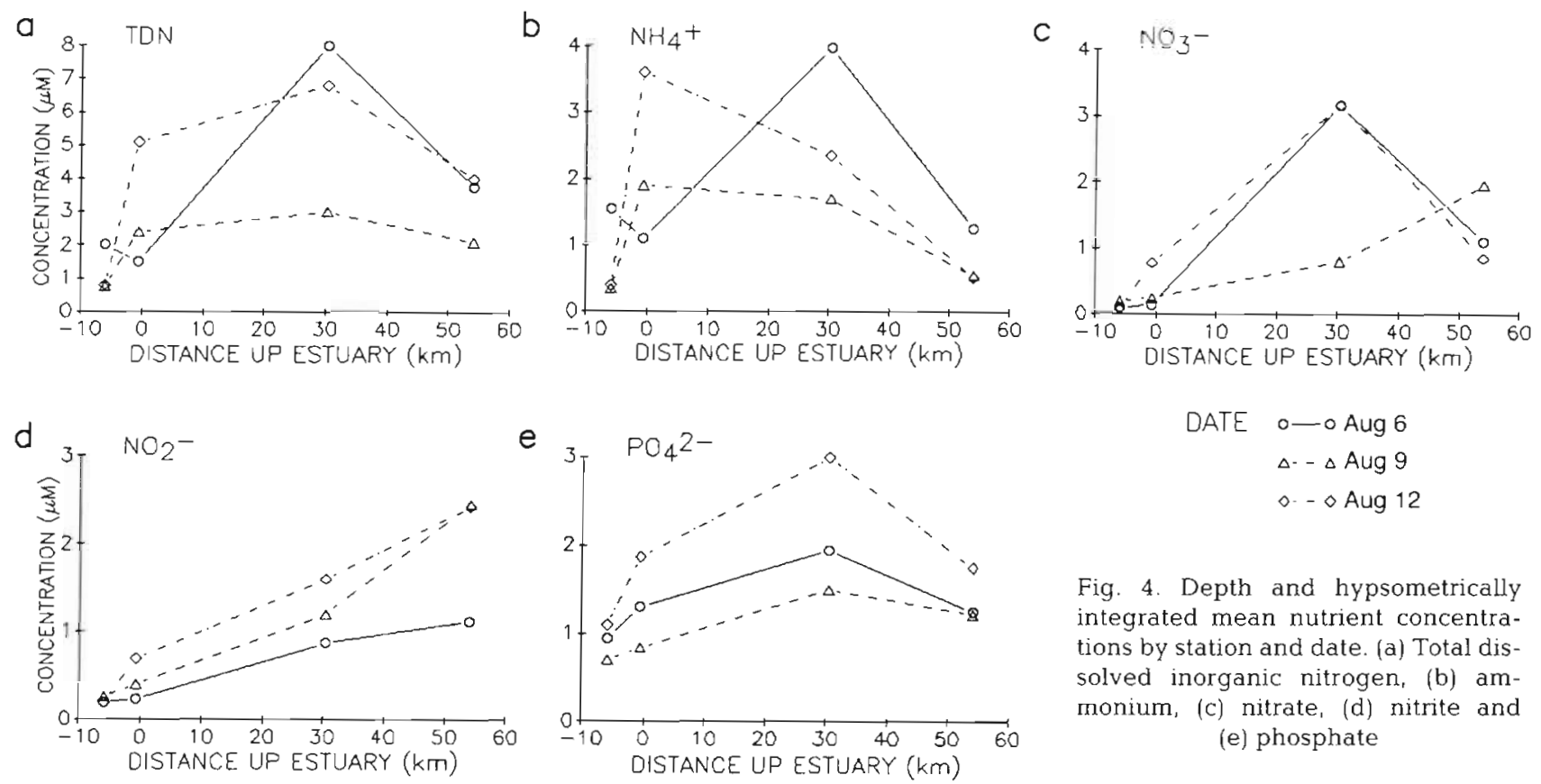

$$
\begin{aligned}
\text { DATE } & \circ-\text { o Aug } 6 \\
& \Delta-\triangle \text { Aug } 9 \\
& \diamond-\diamond \text { Aug } 12
\end{aligned}
$$

Fig. 4. Depth and hypsometrically integrated mean nutrient concentrations by station and date. (a) Total dissolved inorganic nitrogen, (b) ammonium, (c) nitrate, (d) nitrite and

(e) phosphate

at Stn 1 to higher values up-estuary. Temporal patterns of nutrients (with the exception of nitrite) generally indicated nutrient minima on 9 August.

Significant correlations between bacterial abundance and environmental variables were more numerous than between bacterial production and these variables (Table 4a,b). Cyanobacterial abundance, concentrations of ammonium and total dissolved inorganic nitrogen exhibited highly significant ( $p<$ 0.005 ) correlations with both bacterial parameters for the entire data set. Other parameters manifesting highly significant relationships with bacterial abundance included total and $<15 \mu \mathrm{m}$ chl $a_{\text {, diatom }}$ and heterotrophic flagellate abundance, and concentrations of nitrate, nitrite and phosphate. Variables which displayed highly significant correlations with bacterial parameters based upon the entire data set generally demonstrated complex patterns of correlation when examined over spatial and temporal groupings.

Multiple discriminant analyses (MDA) of combination abundance-production groups are shown in Fig. 5. Table 5 presents information on the percent variance described by the discriminant functions, as well as standardized discriminant function coefficients, and correlation coefficients. Discriminant function I (dfI), which tended to effectively separate groups based upon abundance, accounted for $52 \%$ of sample variance but was weakly loaded (low values of correlation coefficients) with many variables. The most important variables on this axis were measures of phaeopigment ratio and dissolved inorganic nutrient concentration.
Discriminant function II (dfII) tended to separate groups based upon production characteristics. This axis accounted for $36 \%$ of sample variance and was more highly loaded by a few variables including dinoflagellate abundance, ammonium and measures of chl a.

Oxygen metabolism experiments conducted during the study (Fig. 6a to c) provided information regarding the nature and mechanism of substrate utilization by heterotrophic bacteria. Dark incubations of surface water samples taken from 2 stations during the day (Fig. 6a) displayed biphasic respiration curves, with slopes diminishing markedly after periods of approximately $1 \mathrm{~h}$. Light pulsing of samples (Fig. 6b) resulted in the reestablishment of the steeper slope characteristic of the initial incubation period. Incubation of a sample taken from Stn 1 in the early evening (Fig. 6c) did not result in a biphasic respiration curve, however amendment of this sample with $10 \mathrm{mg} \mathrm{l}^{-1}$ of glucose resulted in a significantly higher respiration rate.

\section{DISCUSSION}

\section{Trophic relationships}

Comparison of the CVs of plankton taxonomic groups (Table 3 ) indicated that the variability of heterotrophic bacterioplankton was considerably less than that of other plankton constituents. Although bacterial abundance and production were highly correlated for the entire data set, bacterial abundance varied by a factor of 4 


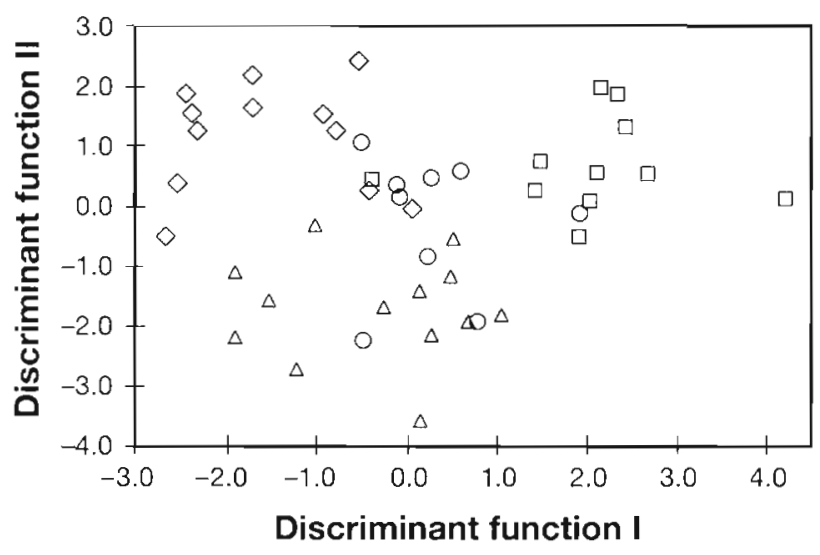

Fig. 5. Multiple discriminant analysis separation of samples within bacterial production-abundance groupings. Groups: $(\Delta)$ low production-low abundance $\left(<190 \mu \mathrm{g} \mathrm{C} \mathrm{ll}^{-1} \mathrm{~d}^{-1}\right.$, $<7.32 \times 10^{6}$ cells $\mathrm{mi}^{-1}$ ), (O) low production-high abundance $\left(<190 \mu \mathrm{g} \mathrm{C} \mu \mathrm{l}^{-1} \mathrm{~d}^{-1},>7.32 \times 10^{6}\right.$ cells $\left.\mathrm{ml}^{-1}\right),(\diamond)$ high production-low abundance $\left(>190 \mu \mathrm{g} \mathrm{C} \mu \mathrm{l}^{-1} \mathrm{~d}^{-1},<8.51 \times 10^{6}\right.$ cells $\mathrm{ml}^{-1}$ ), and ( $\left.\square\right)$ high production-high abundance $(>190 \mu \mathrm{g} \mathrm{C}$ $\mu \mathrm{I}^{-1} \mathrm{~d}^{-1},>8.51 \times 10^{6}$ cells $\mathrm{ml}^{-1}$ )

whereas bacterial production varied by a factor of 7. The relatively invariable nature of bacterioplankton abundance has been discussed by many investigators (e.g. Larsson \& Hagström 1982, Ducklow 1983, Wright \& Coffin 1983b, Malone et al. 1986, Gocke et al. 1987). It is thought that the potential for rapid bacterial biomass accumulation in coastal and estuarine systems (Kirchman et al. 1982, Wright \& Coffin 1983b) is constrained by top-down (grazing) and bottom-up (substrate) influences or by interactions between these factors (Wright 1988, Weisse \& Scheffel-Møser 1991).

Higher bacterial abundances in surface waters of the lower estuary (up to $12.6 \times 10^{6}$ cells $\mathrm{ml}^{-1}$; Table 3, Fig. 4a) parallel the general pattern observed in the Delaware Bay estuary (Coffin \& Sharp 1987, Kirchman \& Hoch 1988) and in the Rhode River estuary, Maryland, USA (Rublee et al. 1984). In other estuarine systems however, bacterial abundance maxima have been observed in midestuary (Wright \& Coffin 1983a) or in upper estuarine regions (Palumbo \& Ferguson 1978, Bell \& Albright 1981, Albright 1983). The location of bacterial abundance maxima within estuarine systems is thought to be a function of substrate availability (Coffin \& Sharp 1987). Since chl a concentrations tended to be higher in the lower estuary, photosynthetically produced dissolved organic matter (PDOM), which can be rapidly utilized by bacterioplankton (Gomes et al. 1991), may have been more important as a source of substrate for bacterial production in this region. Jonas \& Tuttle (1990) found that bacterioplankton abundance and production in the mesohaline portion of the Chesapeake Bay was strongly correlated to dissolved biological oxygen demand (perhaps PDOM) during the summer period. Pelagic oxygen metabolism experiments (Fig. 6a, c), although limited in number, suggested that bacterioplankton in the James River were closely coupled to or limited by available PDOM. Previous work by Ogura (1975) in Tokyo Bay, Japan, has also shown the existence of biphasic metabolic processes but over much longer time scales (days) than observed in this study. The increase in oxygen metabolism rate following glucose amendment is similar to the response observed by Hopkinson et al. (1989) for coastal Georgia waters. These findings, which use oxygen metabolism as a surrogate for bacterial production, along with more direct measurements of microbial response to DOM amendment using ${ }^{3} \mathrm{H}$ thymidine and ${ }^{14} \mathrm{C}$-leucine radioisotopes (Kirchman 1990), further support the notion that the DOM supply
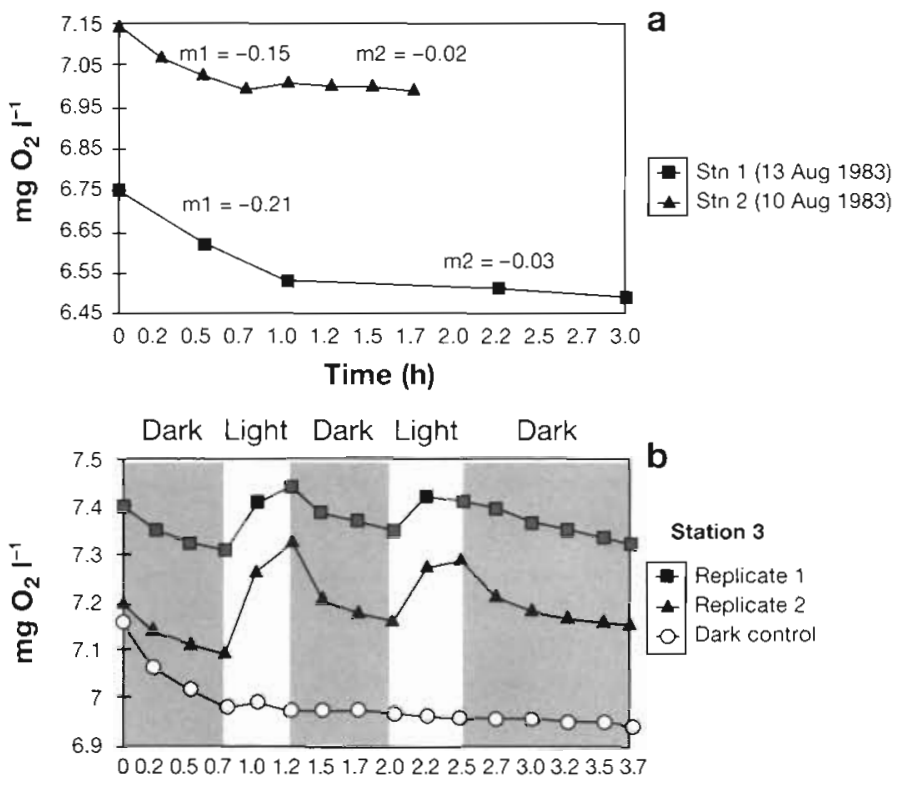

Time (h)

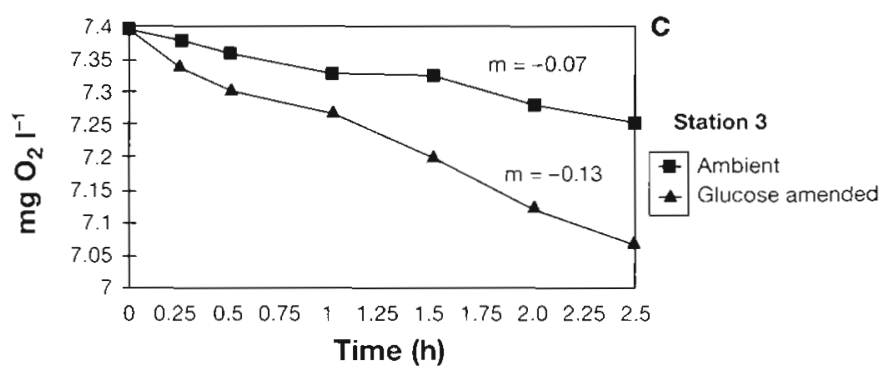

Fig. 6. Results of oxygen metabolism experiments: (a) biphasic metabolic slopes of surface water from Stns 1 \& 2, (b) light pulsing of surface water from $\operatorname{Stn} 3$, (c) giucose amendment $\left(10 \mathrm{mg} \mathrm{l}^{-1}\right)$ of a surface water sample taken during the evening from $\operatorname{Stn} 3$. Oxygen metabolism rates are indicated by figure slope $(\mathrm{m})$ values 
Table 4. Significant Spearman rank coefficients (a) between bacterial abundance and other variables and (b) between bacterial production and other variables. Variables include salinity (SA), temperature (TM), and others as in Table 3. Significance values: $\cdots p \leq 0.005 ; \cdot 0.01 \geq p>0.005 ; \cdot 0.05 \geq p>0.01$

\begin{tabular}{|c|c|c|c|c|c|c|c|c|c|c|c|}
\hline \multirow[t]{3}{*}{ Vanable } & \multicolumn{11}{|c|}{ Data grouping } \\
\hline & \multirow[t]{2}{*}{ Entire } & \multicolumn{3}{|c|}{ Date } & \multicolumn{3}{|c|}{ Depth } & \multicolumn{4}{|c|}{ Stn } \\
\hline & & 6 Aug & 9 Aug & $12 \mathrm{Aug}$ & Surface & Pycnocline & Bottom & 1 & 2 & 3 & 4 \\
\hline \multicolumn{12}{|c|}{ a. Abundance vs variables } \\
\hline $\mathrm{PD}$ & $0.45 \cdots$ & $0.78 \cdots$ & - & _- & $0.40^{\circ}$ & - & - & $0.73 \cdots$ & - & - & - \\
\hline TCHL & $0.54 \cdots$ & $0.69 \cdot$ & - & $0.79 \cdots$ & - & $0.56^{\circ}$ & - & $0.77 \cdots$ & $0.57^{\circ}$ & - & - \\
\hline $\mathrm{SCHL}$ & $0.56 \cdots$ & $0.75 \cdots$ & $0.59^{\circ}$ & $0.58^{\circ}$ & - & $0.58^{\circ}$ & $0.63^{\circ}$ & $0.81 \cdots$ & - & $0.61^{*}$ & - \\
\hline PHA & - & $0.80 \cdots$ & - & - & - & - & - & $0.69 \cdot \cdot$ & - & - & - \\
\hline SPHA & $0.33^{\circ}$ & $0.63^{\circ}$ & - & - & - & - & - & $0.75 \cdots$ & - & - & - \\
\hline LCY & $0.60 \cdots$ & - & $0.81 \cdots$ & $0.67^{\cdots}$ & $0.60 \cdots$ & - & $0.60^{\circ}$ & $0.85 \cdots$ & $0.64^{\circ}$ & - & - \\
\hline LUF & - & - & - & - & - & - & - & - & - & $0.80 \cdots$ & - \\
\hline LDN & $0.26^{\circ}$ & $0.61^{\circ}$ & - & - & $-0.45^{\circ}$ & - & - & - & $0.62^{\circ}$ & - & - \\
\hline LDI & $0.51 \cdots$ & $0.64^{\circ}$ & $0.75^{\circ}$ & - & $0.50^{*}$ & - & - & $0.78 \cdots$ & $0.54^{\circ}$ & - & - \\
\hline LHNAN & $0.43 \cdots$ & - & $0.62^{\circ}$ & $0.53^{\circ}$ & $0.51 \cdots$ & - & - & - & - & - & $-0.57^{\circ}$ \\
\hline NH4 & $-0.46^{\cdots}$ & $-0.76 \cdots$ & - & - & $-0.36^{\circ}$ & - & - & $-0.88 \cdots$ & $-0.61^{\circ}$ & - & - \\
\hline $\mathrm{NO} 2$ & $-0.47 \cdots$ & - & - & $-0.56^{\circ}$ & $-0.74 \cdots$ & - & - & $-0.73 \cdots$ & - & - & - \\
\hline NO3 & $-0.47 \cdots$ & _- & $-0.64^{*}$ & $-0.63^{\circ}$ & $-0.65 \cdots$ & $-0.56^{\circ}$ & - & $-0.65^{\circ}$ & - & - & - \\
\hline $\mathrm{SI}$ & - & $0.51^{\circ}$ & - & $-0.57^{\bullet}$ & $-0.41^{\circ}$ & - & - & - & $0.54^{\circ}$ & - & $-0.67^{\circ}$ \\
\hline $\mathrm{PO} 4$ & $-0.50 \cdots$ & - & $-0.75 \cdots$ & - & $-0.52 \cdot \cdot$ & - & - & - & - & - & - \\
\hline POC & $0.29^{\circ}$ & - & - & $0.59^{\circ}$ & $0.37^{\circ}$ & $0.53^{\circ}$ & - & - & - & - & - \\
\hline PON & $0.30^{\circ}$ & - & $0.57^{\circ}$ & $0.50^{\circ}$ & $0.46^{\circ}$ & - & - & - & - & - & - \\
\hline $\mathrm{SR}$ & - & - & - & $-0.43^{\circ}$ & - & - & - & $0.80^{\cdots}$ & $0.81 \cdots$ & $0.55^{\circ}$ & - \\
\hline SA & - & - & - & - & $0.42^{\circ}$ & - & - & $0.90^{\cdots}$ & - & $-0.56^{\circ}$ & - \\
\hline TM & - & - & _- & - & $-0.54 \cdots$ & - & - & $0.88 \cdots$ & $0.51^{\circ}$ & - & - \\
\hline DO & $0.26^{\bullet}$ & - & - & - & - & - & - & - & - & - & - \\
\hline \multicolumn{12}{|c|}{ b. Production vs variables } \\
\hline $\mathrm{PD}$ & $0.45 \cdots$ & $0.78 \cdots$ & _- & - & $0.40^{\circ}$ & - & - & $0.73 \cdots$ & - & - & - \\
\hline TCHL & $0.29^{\circ}$ & $0.65^{\circ}$ & - & - & - & - & - & $0.57^{\circ}$ & - & - & - \\
\hline $\mathrm{SCHL}$ & $0.38^{\circ}$ & $0.75 \cdots$ & - & - & - & - & - & $0.63^{\circ}$ & & $0.72 \cdots$ & - \\
\hline PHA & $0.28^{\circ}$ & $0.81 \cdots$ & - & - & - & - & - & $0.68^{*}$ & - & - & - \\
\hline SPHA & $0.34^{\circ}$ & - & $0.58^{\circ}$ & - & - & - & $0.65^{\circ}$ & - & - & - & $0.54^{\circ}$ \\
\hline $\mathrm{LCY}$ & $0.45 \cdots$ & $0.61^{\circ}$ & - & - & - & $0.78 \cdots$ & - & $0.75 \cdots$ & - & - & - \\
\hline LUF & - & - & - & - & - & - & - & - & - & $0.63^{\circ}$ & - \\
\hline LDN & $0.28^{\circ}$ & - & $0.64^{\circ}$ & - & - & - & $0.65^{\circ}$ & - & - & $0.92 \cdots$ & - \\
\hline LDI & $0.36^{*}$ & $0.77 \cdots$ & - & - & - & - & - & - & - & $0.83 \cdots$ & - \\
\hline LHNAN & $0.25^{\circ}$ & $0.61^{\circ}$ & - & - & - & $0.66^{\circ}$ & $-0.56^{\circ}$ & $0.69^{\circ}$ & - & - & $0.17^{\circ}$ \\
\hline $\mathrm{NH} 4$ & $-0.52 \cdots$ & $-0.71^{\circ}$ & - & $-0.51^{\circ}$ & - & - & $-0.73 \cdots$ & $-0.56^{\circ}$ & - & $-0.73 \cdots$ & - \\
\hline $\mathrm{NO} 2$ & - & - & - & - & $-0.44^{\circ}$ & - & - & - & $-0.52^{\circ}$ & - & - \\
\hline $\mathrm{NO} 3$ & $-0.26^{\circ}$ & - & - & - & - & $-0.61^{\circ}$ & - & - & $-0.50^{\circ}$ & - & - \\
\hline SI & - & - & - & - & - & - & - & $0.56^{\circ}$ & - & - & $0.25^{\circ}$ \\
\hline $\mathrm{PO} 4$ & $-0.35^{\circ}$ & - & - & - & - & - & $-0.56^{\circ}$ & - & - & - & - \\
\hline POC & - & - & - & - & - & - & - & - & - & - & - \\
\hline PON & - & - & - & - & - & - & - & - & - & - & - \\
\hline SR & - & - & - & - & - & $-0.68^{\circ}$ & - & - & - & $0.76 \cdots$ & - \\
\hline $\mathrm{SA}$ & - & - & - & - & - & - & - & $-0.64^{\circ}$ & - & $-0.83 \cdots$ & - \\
\hline $\mathrm{TM}$ & - & - & - & - & - & - & - & $0.54^{\circ}$ & - & $0.57^{\circ}$ & - \\
\hline DO & $0.24^{\circ}$ & - & - & - & - & - & $0.54^{\circ}$ & - & - & - & - \\
\hline
\end{tabular}

rate can limit bacterial production in a variety of marine and estuarine habitats.

Further evidence suggesting linkages between heterotrophic bacteria and the phytoplankton community included CV patterns similar to chlorophyll (Table 3), and highly significant correlations ( $p<0.005$ ) between bacterial abundance and both total and $<15 \mu \mathrm{m}$ of chlorophyll (Table 4a). Our findings augment numerous studies reporting positive correlations between bacterial abundance and chlorophyll (Fuhrman et al. 1980, Griffiths et al. 1982, Linley et al, 1983, Bird \& Kalff 1984, Lancelot \& Billen 1984, Fuhrman et al. 1985, Laanbroek et al. 1985, Malone et al. 1986, and see review by Cole et al. 1988). The overall regression relationship between direct counts (DC, cells $\mathrm{ml}^{-1}$ ) of

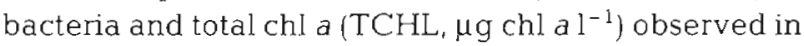
this study was: $\log _{10} \mathrm{DC}=6.45+0.43 \log \mathrm{TCHL}(\mathrm{n}=47$. $\mathrm{R}^{2}=0.51$ ). This relationship is similar to that found by Malone et al. (1986) for stratified water at stations transecting the normal axis of the upper Chesapeake Bay, which was: $\log _{10} \mathrm{DC}=6.52+0.45 \log \mathrm{TCHL}(\mathrm{n}=160$, $\left.\mathrm{R}^{2}=0.83\right)$. These regression relationships differ markedly from those determined from literature reviews by Bird \& Kalff (1984) and Cole et al. (1988), displaying bacterial abundances approximately onehalf $\log$ unit greater at the zero chl a intercept, and 
Table 5. Multiple discriminant analysis results of bacterial abundance-production employing a direct analysis procedure with a tolerance of 0.01 Results include percent variance described by discriminant functions (dfI, dfII), correlations between variables and discriminant functions $(\alpha)$, and standardized correlation coefficients $(\beta)$. Discriminant function lII is not shown, and was not statistically significant in group separation

\begin{tabular}{|lrrrr|}
\hline Variable & \multicolumn{2}{c}{ dfI } & \multicolumn{2}{c|}{ dfli } \\
& \%Variance: 51.5 & \multicolumn{2}{c|}{35.8} \\
& $\alpha$ & $\beta$ & $\alpha$ & $\beta$ \\
\hline NO2 & -0.27 & -0.20 & -0.04 & -0.46 \\
PHA & 0.26 & 1.01 & 0.22 & -0.23 \\
SPHA & 0.26 & -0.07 & -0.25 & -0.13 \\
LDI & 0.25 & 0.67 & -0.23 & -0.38 \\
PO4 & -0.25 & -0.48 & 0.35 & 0.72 \\
NO3 & -0.23 & -0.22 & 0.18 & 0.12 \\
LCY & 0.22 & 0.22 & -0.33 & 0.79 \\
NH4 & -0.22 & -0.30 & 0.50 & 0.09 \\
SCHL & 0.14 & -0.77 & -0.51 & -0.62 \\
TCHL & 0.13 & 1.03 & -0.37 & 0.80 \\
SA & 0.12 & 8.05 & 0.14 & 11.4 \\
SR & -0.11 & 7.57 & -0.12 & 12.3 \\
TM & -0.08 & 0.72 & -0.19 & -0.36 \\
LDN & -0.06 & -1.11 & -0.64 & -0.83 \\
LUF & -0.06 & -0.86 & 0.04 & 0.49 \\
LHNAN & -0.03 & -0.39 & -0.01 & -0.32 \\
\hline
\end{tabular}

lower regression slope values. In fact, bacterial abundance observed in Chesapeake Bay studies (Malone et al. 1986, Ducklow \& Peele 1987, Jonas \& Tuttle 1990, present study) are among the highest reported for estuarine environments. Ducklow \& Peele (1987) found that in the mid Chesapeake Bay bacterial biomass often exceeded phytoplankton biomass by a factor of 3 during the summer season. In the present study bacterial biomass averaged $20 \%$ of chlorophyll indicated phytoplankton biomass, however bacterial production rates averaged $80 \%$ of areal primary production rates (unpubl. data) measured on $9 \& 12$ August. Elevated bacterial biomass and production rates in the Chesapeake Bay and its subestuaries may reflect high inputs of allochthonous carbon and nutrients and/or high rates of inorganic and organic nutrient recycling between components in the microbial loop.

Correlative relationships between bacteria and total chl $a$ at Stn 1 in the lower estuary were stronger than at other stations. This may have resulted from the increased water column depth at the mouth of the estuary, which minimized wind-driven mixing, thereby allowing greater differences between surface and bottom plankton communities. A similar trend in correlations of bacterial abundance with concentrations of DOM as indicated by salinity residuals (sensu Foster \& Morris 1974) was observed at Stns $1 \& 2$ in the lower estuary (Table $4 \mathrm{a}, \mathrm{b}$ ). Although associations between bacterioplankton abundance and total chl a concentration in the euphotic zone were anticipated, they were not observed. Relationships between bacterial abundance and bacterial production with total chl $a$ in surface waters may have been obscured by the grazing activities of flagellates, which were highly correlated ( $p<0.001$ ) with bacterial abundance in surface waters. In pycnocline and bottom waters, where no relationships between bacteria and flagellates were found, weak relationships $(0.05 \geq p \geq 0.01)$ to total and $<15 \mu \mathrm{m}$ chl a were observed.

Correlations of bacterial abundance and production with $<15 \mu \mathrm{m}$ chl $a$ and cyanobacterial abundance (based upon the entire data set; Table $4 \mathrm{a}, \mathrm{b}$ ) suggested stronger relationships between bacteria and these smaller phytoplankton assemblages as compared to the total phytoplankton population. MDA suggested similar findings, since loadings of $<15 \mu \mathrm{m}$ chl $a$ and cyanobacteria on dfI and dfII (Table 5) were higher than for total chlorophyll a. $<15 \mu \mathrm{m}$ chl a was highly loaded on dfII, which discriminated between bacterial production groupings. Such findings are reasonable if these smaller forms comprised a major portion of the biomass or were important in the production of dissolved organic carbon (DOC) in the phytoplankton community. In this study chlorophyll $<15 \mu \mathrm{m}$ averaged $75 \%$ of total chlorophyll. Similar proportions (88\%) of $<15 \mu \mathrm{m}$ chl a have been observed in the York River during the fall by Ray et al. (1988).

Relationships between cyanobacterial and heterotrophic bacterial abundance were strong despite the minimal contribution of cyanobacterial carbon to total autotrophic biomass (mean of $6 \%$ using $115 \mathrm{fg} \mathrm{C}$ cellas in Ray et al. 1988). The correlation $\mathrm{r}^{2}$ and frequency of significant correlations between heterotrophic bacterial parameters and cyanobacterial abundance were greater than bacterial correlations with other autotrophic parameters (Table $4 \mathrm{a}$, b). Hagström et al. (1988) found that protozooplankton grazing of cyanobacteria and the associated addition of substrate to the DOM pool via sloppy feeding may provide an indirect yet strong coupling between cyanobacteria and heterotrophic bacteria. Such an energy flow was probably important in the present study, given the high abundances of cyanobacteria observed (mean = $3.0 \times 10^{5}$ cells $\mathrm{ml}^{-1}$ ).

MDA and correlation analysis of the phaeopigment ratio (also called the acidification ratio) indicated that bacterioplankton were more abundant and productive when phaeopigment contribution to total pigments was low. Phaeopigment ratios indicate the relative proportions of chlorophyll to chlorophyll degradation products (phaeopigments), with lower ratios indicating a predominance of phaeopigments. Herbivorous zooplankton grazing can generate phaeopigments due to 
sloppy feeding and passage of labile photopigments through their guts (Welschmeyer \& Lorenzen 1985, Litaker et al. 1988). Total and < $15 \mu \mathrm{m}$ phaeopigment ratios were found by MDA to be highly loaded on dfI, which discriminated between low and high bacterial abundance groupings (Table 6). This suggests that the presumed coupling of phytoplankton with bacteria was due to the excretion of PDOM by healthy phytoplankton cells and not due to herbivory or cellular lysis. Highly significant positive correlations between bacterial parameters and total phaeopigment ratios were observed on 6 August (Table 4), but disappeared following destratification and mixing of the water column. Although herbivory can be important in generating a source of DOM substrates for bacteria (Hagström et al. 1988, Jumars et al. 1989), our data suggest it was of minor importance in this study. This was further substantiated by the results of the oxygen metabolism experiment data (Fig. 6a to c), which also suggested that the major bacterial substrates were PDOM.

Heterotrophic nanoflagellates (HNAN) appeared important in the control of bacterioplankton during the course of this study. High HNAN abundances were generally associated with stations exhibiting high bacterial abundance and production rates (surface water, Stns 1 \& 2). The mean ratio of bacteria to HNAN was ca $2000: 1$, very similar to that observed by McManus \& Fuhrman (1988) for the Chesapeake Bay plume. This ratio is somewhat high relative to the recent literature review findings of Sanders et al. (1992) (ca 1000:1), and may reflect a 'trophic cascade', where higher-trophic-level grazing upon HNAN permits higher bacterial abundances. Bacterial abundance displayed a highly significant positive correlation with HNAN abundance based upon the entire data set, yet correlations based upon temporal and spatial groupings revealed only a single highly significant relationship in surface waters. The existence of such a strong correlation was somewhat unexpected, given the generally observed time-lagged relationships between these groups in field and in vitro studies (Fenchel 1982, Anderson \& Sørensen 1986, Bjørnsen et al. 1988). Flagellate bacterial interactions may have been more pronounced in surface waters for a number of reasons. Sibbald et al. (1987) showed that HNAN display positive chemotaxis towards amino acids and ammonium. The release of PDOM by phytoplankton cells in photic-zone surface waters may give rise to locally high substrate availability and hence greater production rates and abundances of heterotrophic bacteria. This, in combination with the release of dissolved organics (i.e. amino acids) (Andersson et al. 1985, Taylor et al. 1985) and inorganic nutrients (see review by Caron \& Goldman 1990) during HNAN grazing upon surface water microbial populations, is likely to promote greater bacterial production and a positive feedback
Table 6. Estimated surface-water grazing rates of microzooplankton on bacteria over sampling intervals. TGR (total grazing rate, cells ml-1 $\left.\mathrm{d}^{-1} \times 10^{7}\right]=B A_{n}+\left[\left(B P_{n}+B P_{n+1}\right) / 2\right]-B A_{n+1}$, where $B A_{n}$ and $B A_{n+1}=$ bacterial abundance at the beginning and end of the interval; $B P_{n}$ and $B P_{n+1}=$ bacterial production at the beginning and end of the interval

\begin{tabular}{|lcrr|}
\hline Interval & Stn & TGR & PPG \\
\hline 6-8 August & 1 & 1.68 & 104 \\
& 2 & 1.59 & 99 \\
8-9 August & 3 & 1.44 & 117 \\
& 4 & 1.05 & 108 \\
& 2 & 1.00 & 90 \\
9-10 August & 3 & 0.98 & 98 \\
& 4 & 0.84 & 87 \\
& 2 & 1.15 & 117 \\
10-12 August & 3 & 1.19 & 107 \\
& 4 & 1.52 & 105 \\
& 2 & 0.78 & 97 \\
$12-13$ August & 1 & 0.93 & 89 \\
& 3 & 1.54 & 93 \\
& 2 & 1.21 & 98 \\
& 3 & 1.01 & 97 \\
& 4 & 1.88 & 103 \\
& 4 & 1.01 & 124 \\
& 1.07 & 132 \\
& & 0.71 & 85 \\
\hline
\end{tabular}

response in both HNAN and phytoplankton populations (Stone 1990). Finally, greater interactions between HNAN and bacteria would have occurred in surface waters simply based upon the probability of encounter. The ratio of bacteria to HNAN was significantly greater in surface waters than in bottom waters (1-tailed $t$-test, $\mathrm{p} \leq 0.001)$.

Direct measurement of HNAN bacterial grazing rates were not obtained in this study. However, maximum grazing rates upon bacteria were estimated from bacterial abundance and cellular production data (Table 6). These calculations assume the absence of bacterial cell emigration and non-predatory mortality, and reflect the combined activities of all potential grazers including HNAN and heterotrophic ciliates (Sherr \& Sherr 1977, Sherr et al. 1989). Based upon the aforementioned assumptions, the total grazing rate (TGR) in

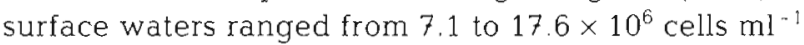
$\mathrm{d}^{-1}$ (mean $\left.=12 \times 10^{6} \mathrm{ml}^{-1} \mathrm{~d}^{-1}\right)$. These theoretical rates are somewhat higher than the results from direct measurements made by Coffin \& Sharp (1987) in the Delaware Bay and by Sherr et al. (1989) in tidal creeks of Sapelo Island, Georgia, USA ( 8 and $9.6 \times 10^{6}$ cells $\mathrm{ml}^{-1} \mathrm{~d}^{-1}$ maximum respectively), but could be supported by the observed HNAN populations alone, given literature findings on HNAN clearance rates (Capriulo 1990). Conversion of grazing rates to \% loss 
of daily bacterial production revealed that from 85 to $132 \%$ of daily bacterial production would be consumed through grazing. A SAS (Systat, Inc.) general linear model analysis indicated that $T G R$ was significantly different among stations $(p=0.028)$, with the difference confined to end-member Stns 1 \& 4 . Although the number of grazing estimates was small $(n=20)$, our results were similar to those obtained by Coffin \& Sharp (1987) for the Delaware Bay estuary, to the extent that both bacterial production and bacterial grazing rates were highest in the lower estuary. Temporal patterns indicated depression of TGR during the onset of destratification. TGR for the interval of 8-9 August was significantly lower $(28 \%$ lower, $p \leq$ $0.05)$ compared to the first interval. It appears then that the decrease in bacterial production and the concomitant decrease in microzooplankton grazing, both of which occurred during destratification, were responsible for the temporal stability of bacterial abundance in this study. Our findings, though based upon theoretical rates and not specific to grazer type, show a parallel to results of McManus \& Peterson (1988), who observed disruptions of HNAN grazing activities during destratification events in the coastal zone off Chile.

\section{Bacterial-nutrient dynamics}

Correlations between bacterial abundance and dissolved nitrogen and phosphorus nutrients were negative and highly significant for the entire data set. Rublee et al. (1984) observed similar relationships with ammonium and nitrate in the Rhode River estuary, but reported a positive relationship with phosphorus. In the present study correlations of nutrients with bacterial abundance (Table 4a) were all more highly significant than analogous correlations to total chlorophyll a (data not shown), suggesting that the relationships between bacteria and nutrients were not indirectly due to nutrient uptake and activity by phytoplankton.

Multiple discriminant analysis (Fig. 5, Table 5) indicated that nitrite concentration was the most important discriminatory variable with regard to bacterial abundance, while ammonium concentration was an important discriminator of production groups. Phosphate displayed moderately high loadings on both dfI and dfII and therefore contributed somewhat to separation of all groups. A basic question with regard to these data is why relationships between nutrients and bacterial abundance should differ from relationships between nutrients and bacterial production. Perhaps certain nutrients differentially influence constituents of the microbial loop whose interactions with bacteria are important in determining bacterial abundance. For example, heterotrophic flagellates displayed significant negative cor- relations ( $p<0.001$, data not shown) to nitrite concentrations based upon the entire data set, and therefore discrimination of bacterial abundance groups by nitrite may be indirectly related to flagellate activities.

Temporal changes in nutrient concentrations revealed patterns observed previously by Webb \& D'Elia (1980) during a spring-neap tidal cycle in the York River. Integrated water-column concentrations of ammonium, total dissolved inorganic nitrogen (DIN) and phosphate grouped over stations displayed minima that coincided with destratification on 9 August (Fig. $4 \mathrm{a}$ to e). After restratification, phosphate concentrations increased to levels greater than observed prior to destratification. The most marked temporal change in DIN nutrients occurred at Stn 3, where integrated concentrations of total DIN, ammonium, and nitrate all decreased from 60 to $70 \%$ between 6 and 9 August. This phenomenon coincided with a rapid increase in integrated $\mathrm{chl}$ a concentration and therefore was probably due to nutrient uptake associated with autotrophic growth. Temporal changes in correlations between heterotrophic bacteria and dissolved nutrients were apparent for various nutrient species. On 6 August, bacteria were highly correlated with ammonium, yet by 9 August, this relationship disappeared and was replaced instead by a strong correlation to phosphate and weaker correlations to oxidized nitrogen nutrients.

Phytoplankton ammonium uptake has been shown to suppress enzymes responsible for nitrate assimilation (Carpenter \& Dunham 1985). It is likely that the importance of oxidized nitrogen forms for autotrophic assimilation increases as ammonium concentrations decline. Price et al. (1985) and Harrison \& Wood (1988) have demonstrated that uptake rates and preference for certain nitrogen nutrient species by autotrophs may be dramatically affected by the hydrography (stratified vs frontal) of the system. However, similar information concerning heterotrophic bacteria is still lacking. Billen (1984) concluded that bacteria utilize primarily amino acids as their nitrogen source, while phytoplankton utilize ammonium, nitrate and urea. However, work by Wheeler \& Kirchman (1986), Fuhrman et al. (1988), and by Koepfler et al. (York River, unpubl.) has shown that in the euphotic zone significant amounts of ammonium uptake into particulate material were due to assimilation by heterotrophic bacteria.

Correlation analysis indicated a weakening in the relationship between bacterial abundance and nutrients with depth in the water column (Table $4 \mathrm{a}, \mathrm{b}$ ). Strong negative correlations with oxidized forms of nitrogen and weaker relationships with ammonium and phosphate were found in the surface waters. Pycnocline waters exhibited only weak correlations between oxidized nitrogen forms and bacterial abun- 
dance. Bottom waters yielded no significant correlations between nutrients and bacterial abundance. It is highly probable that nutrient concentrations under the pycnocline are influenced by benthic regeneration and consumption processes, and these processes obscure relationships which may exist between planktonic components and nutrients in bottom waters. Correlations of nutrients to bacterial abundance based upon stations displayed a pattern similar to that seen for cyanobacteria and chlorophyll $a$, with strong correlations to all nitrogen nutrient species at Stn 1 and generally decreasing associations to nutrients progressing upriver.

\section{Hydrographic influences}

In pelagic ecosystems with temporally persistent conditions, the structure of the pelagic food web appears to be a system based on a longer microbial loop under stratified hydrography, while the shorter 'classic' food web system prevails under mixed hydrography (Cushing 1988, Kiørboe et al. 1990). However, these findings do not address ecosystems such as estuaries that possess hydrographies that may change from stratified to mixed and back on the order of days.

Investigations of oceanic and coastal environments have generally shown heterotrophic bacterial production in the euphotic zone of stratified waters to exceed that observed under mixed conditions (Table 7). In the upper Chesapeake Bay, Malone et al. (1986) observed that bacterial production ranged from 52 to $680 \mathrm{mg} \mathrm{C} \mathrm{m}^{-2} \mathrm{~d}^{-1}$ during mixed conditions, versus 250 to $1000 \mathrm{mg} \mathrm{C}$ $\mathrm{m}^{-2} \mathrm{~d}^{-1}$ under stratified hydrography. Results of the present study indicate that the same pattern occurs in the James River. Depth-integrated bacterial production grouped over stations decreased significantly ( $p=0.015$, SAS-General linear model) from $324 \mu \mathrm{g} \mathrm{Cl}^{-1} \mathrm{~d}^{-1}$ on 6 August to $187 \mu \mathrm{g}$ $\mathrm{C}^{-1} \mathrm{~d}^{-1}$ on 9 August, the date of greatest mixing. Reduction of bacterial production with mixing of the water column may be due to an uncoupling between bacterioplankton and substrate supplied from euphotic phytoplankton components (Malone et al. 1986, McManus \& Peterson 1988). Several mechanisms may promote this uncoupling, including depression of primary productivity under

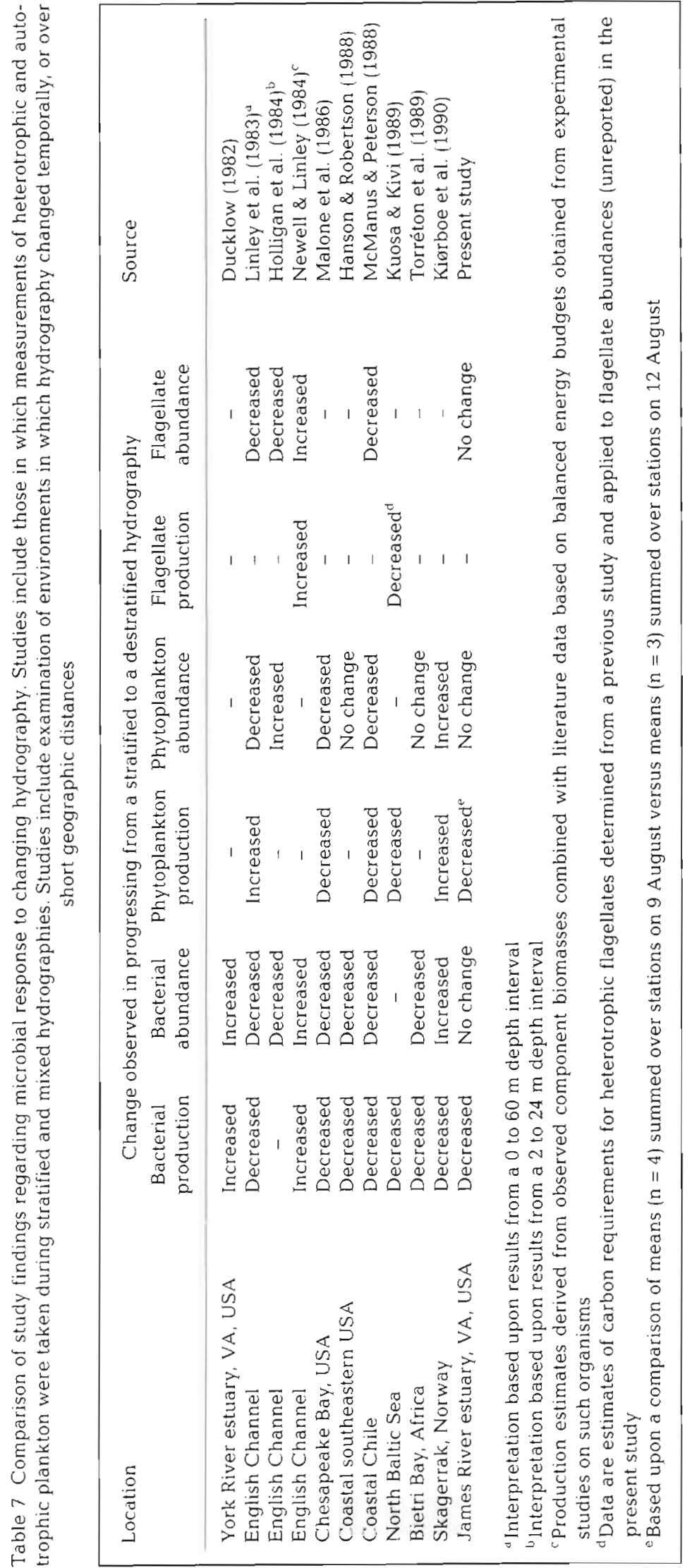


light-limited conditions of destratification (see review by Legendre 1981), reduction in PDOM excretion rates with increasing nutrient concentration (Joiris et al. 1982) or simple mixing and dilution of euphotic zone PDOM substrates. Malone et al. (1986) found that rates of primary production in the upper Bay were lower under mixed conditions than during the stratified state. In the present study, a limited number of ${ }^{14} \mathrm{C}$ primary production estimates were obtained on 9 \& 12 August (unpubl. data). Mean rates of ${ }^{14} \mathrm{C}$ primary production grouped over stations were ca 3 times higher on 12 August $\left(9.13 \mathrm{~g} \mathrm{C} \mathrm{m}^{-2} \mathrm{~d}^{-1}\right)$ than 9 August $(3.24 \mathrm{~g} \mathrm{C}$ $\mathrm{m}^{-2} \mathrm{~d}^{-1} \mathrm{j}$, the date of maximum destratification. Further indications of trophic uncoupling upon destratification were evident from correlation analysis. Relationships between bacterial abundance and both measures of chlorophyll were more highly significant on 6 August than on 9 August, when they were weak or absent. Relationships between bacterial production and chl a displayed a similar pattern. By 12 August, when the stations had begun to restratify, more highly significant correlations reappeared between chl $a$ and bacterial parameters. Malone et al. (1986) also found that correlation coefficients between direct counts of bacteria and chl a were higher during stratified hydrography as compared to the mixed period.

Increases in chl $a$ in pycnocline and bottom waters combined with a depression in surface water chl a values at Stns 1 to 3 on 10 August suggested mixing of surface water chlorophyll throughout the water column. Although this would reduce bacterial substrate (PDOM) in the surface waters, increased chlorophyll in euphotic waters may be accompanied by increased substrate to those bacterial populations. Substrate relocation may explain why bacterial production increased over the study in pycnocline waters (Fig. 2f). Mechanisms to explain the influence of destratification upon relationships between heterotrophic bacteria and cyanobacteria are speculative. Morris \& Glover (1981) have found that Synechococcus sp. (the numerically dominant autotroph during this study) contribute proportionately more towards total primary production under low light conditions than under high light conditions. In the York River estuary, Ray et al. (1988) also found that the percent of total primary production attributable to cells $<3 \mu \mathrm{m}$ (primarily Synechococcus) was negatively correlated with light. It is possible that cyanobacterial production assumed a greater proportion of total primary production as destratification progressed in the James River. Increased turbidity associated with destratification would be likely to enhance this process. Alternatively, increasing abundances of cyanobacteria in pycnocline and bottom waters could have been due to advection of populations from the surface waters. Regardless of the mechanism, bacterial production in pycnocline waters was strongly associated with cyanobacterial abundance (Table $4 \mathrm{~b}$ ).

The consequences of destratification may depend upon the type of controls exerted upon bacterial populations when destratification occurs. Depression of bacterial production rates would be likely if surface water populations were close to substrate-limited conditions with regard to carbon, and destratification further diluted avallable substrate. Enhancement of rates could occur if surface populations were nutrient limited and mixing of nutrient-rich bottom waters provided increased concentrations throughout a greater portion of the water column. If the grazing activities of microheterotrophs and bacterial production were depressed during destratification, then bacterial abundance would appear constant.

This study has illustrated that bacterioplankton activities and trophic relationships in the microbial loop are markedly altered during destratification. Since hydrographic phenomena such as destratification occur on a regular basis in many temperate estuaries, it is of great importance and interest to determine how these changes affect the microbial loop. In particular, more information is needed regarding qualitative and quantitative changes in microbial substrates and changes in the activities of grazers as the result of hydrographic alterations.

Acknowledgements. We are indebted to Evon Ruzecki for access to physical oceanographic information. We also thank Martha Rhodes and Jane Wingrove for help in preparation for microbiological sampling. This work was partially supported by NSF grant OCE $81-10396$ to L.W.H., and was conducted as a partial requirement of the senior author's Dissertation at the Virginia Institute of Marine Science - College of William \& Mary. Thanks are also due to H. Chin-Leo, and R. Dame for reviewing the manuscript. Contribution 1796 of the Virginia Institute of Marine Science

\section{LITERATURE CITED}

Albright, L. J. (1983). Heterotrophic bacterial biomass and productivities with the Fraser River plume. Can. J. Fish. Aquat. Sci. 40: 216-220

Anderson, P., Sørensen, H. M. (1986). Population dynamics and trophic coupling in pelagic microorganisms in eutrophic coastal waters. Mar. Ecol. Prog. Ser. 33: 99-109

Andersson, A., Lee, C., Azam, F., Hagström, A. (1985) Release of amino acids and inorganic nutrients by heterotrophic marine microflagellates. Mar. Ecol. Prog. Ser. 23: $99-106$

Azam, F., Fenchel, T., Field, J. G., Gray, J. S., Meyer-Reil, L. A., Thingstad, F. (1983). The ecological role of water column microbes in the sea. Mar. Ecol. Prog. Ser. 10: $257-263$

Bell, C. R., Albright, L. J. (1981). Attached and free floating bacteria in the Fraser River estuary, British Columbia, Canada. Mar. Ecol. Prog. Ser. 6: 317-327

Billen, G. (1984). Heterotrophic utilization and regeneration of nitrogen. In: Hobbie, J. E., Williams, P. J. (eds.) Hetero- 
trophic activity in the sea. Plenum Press, New York, p. 313-355

Bird, D. F., Kalff, J. (1984). Empirical relationships between bacterial abundance and chlorophyll in fresh and marine waters. Can. J. Fish. Aquat. Sci. 41: 1015-1023

Bjornsen, P. K., Riemann, B., Horsted, S. J., Neilsen, T. G., PockStern, J. (1988). Trophic interactions between heterotrophic nanoflagellates and bacterioplankton in manipulated seawater enclosures. Limnol. Oceanogr. 33: 409-420

Capriulo, G. M. (1990). Feeding related ecology of marine protozoa. In: Capriulo, G. M. (ed.) Ecology of marine protozoa. Oxford Univ. Press, New York, p. 186-259

Caron, D. A., Goldman, J. C. (1990). Protozoan nutrient regeneration. In: Capriulo, G. M. (ed.) Ecology of marine protozoa. Oxford Univ. Press, New York, p. 283-306

Carpenter, E. J., Dunham, S. (1985). Nitrogenous nutrient uptake, primary production, and species composition of phytoplankton in the Carmans River estuary, Long Island, New York. Limnol. Oceanogr. 30: 513-526

Chróst, R. H., Faust, M. A. (1983). Organic carbon release by phytoplankton: its composition and utilization by bacterioplankton. J. Plankton Res. 5: 477-493

Coffin, R. B., Sharp, J. H. (1987). Microbial trophodynamics in the Delaware estuary. Mar. Ecol. Prog. Ser. 41: 253-266

Cole, J. J., Findlay, S., Pace, M. L. (1988). Bacterial production in fresh and saltwater ecosystems: a cross-system overview. Mar. Ecol. Prog. Ser. 43: 1-10

Cushing, D. H. (1988). A difference in structure between ecosystems in strongly stratified waters and those that are only weakly stratified. J. Plankton Res. 11: 1-13

Ducklow, H. W. (1982). Chesapeake Bay nutrient and plankton dynamics. 1. Bacterial biomass and production during spring tidal destratification in the York River, Virginia, estuary. Limnol. Oceanogr. 27: 651-659

Ducklow, H. W. (1983). Production and fate of bacteria in the oceans. BioSci. 33: 494-500

Ducklow, H., Peele, E. (1987). Bacterial carbon pools and fluxes in Chesapeake Bay plankton. In: Mackiernan, G. (ed.) Dissolved oxygen in the Chesapeake Bay: processes and effects. Maryland Sea Grant, College Park, p. 81-85

Fenchel, T. (1982). Ecology of heterotrophic microflagellates. IV. Quantitative occurrence and importance as bacterial consumers. Mar. Ecol. Prog. Ser. 9: 35-42

Foster, P., Morris, A. W. (1974). Seasonal distribution of ultraviolet absorption in the surface waters of Liverpool Bay. Estuar. coast. mar. Sci. 2: 283-290

Fuhrman, J. A., Ammerman, J. W., Azam, F. (1980). Bacterioplankton in the coastal euphotic zone: distribution, activity and possible relationships with phytoplankton. Mar. Biol. 60: $201-207$

Fuhrman, J. A., Azam, F. (1980). Bacterioplankton secondary production estimates for coastal waters of British Columbia, Antarctica, and California. Appl, environ. Microbiol. 39: 1085-1095

Fuhrman, J. A. Azam, F. (1982). Thymidine incorporation as a measure of heterotrophic bacterioplankton production in marine surface waters: evaluation and field results. Mar. Biol 66: 109-120

Fuhrman, J. A., Eppley, R. W., Hagström, A., Azam, F. (1985). Diel variations in bacterioplankton, phytoplankton, and related parameters in the southern California Bight. Mar. Ecol. Prog. Ser. 27: 9-20

Fuhrman, J. A., Horrigan, S. G., Capone, D. G. (1988). Use of ${ }^{13} \mathrm{~N}$ as a tracer for bacterial and algal uptake of ammonium from seawater. Mar. Ecol. Prog. Ser. 45: 271-278

Gocke, K., Kremling, K., Osterroht, C., Wenck, A. (1987). Short-term fluctuations of microbial and chemical vari- ables during seasons in coastal Baltic waters. Mar. Ecol. Prog. Ser. 40: $137-144$

Gomes, H., Pant, A., Goes, J. I., Parulekar, A. H. (1991). Heterotrophic utilization of extracellular products of phytoplankton in a tropical estuary. J. Plankton Res. 13: $487-498$

Griffiths, R. P., Caldwell, B. A., Morita, R. Y (1982). Seasonal changes in microbial heterotrophic activity in subarctic marine waters as related to phytoplankton primary productivity. Mar. Biol. 7: 121-127

Haas, L. W. (1977). The effect of the spring-neap tidal cycle on the vertical salinity structure of the James, York, and Rappahannock Rivers, Virginia, U.S.A. Estuar. coast. mar. Sci. 5: $485-496$

Haas, L. W. (1982). Improved epifluorescence microscopy for observing planktonic microorganisms. Annls Inst. océanogr., Paris 58: 940-946

Haas, L. W., Hastings, S. J., Webb, K. L. (1981). Phytoplankton response to a stratification-mixing cycle in the York River estuary during late summer. In: Neilson, B. J., Cronin, L. E. (eds.) Estuaries and nutrients. Humana Press, Clifton, NJ, p. $619-636$

Haas, L. W., Webb, K. L. (1979). Nutritional mode of several non-pigmented microflagellates from the York River Estuary, Virginia. J. exp. mar. Biol. Ecol. 39: 125-134

Hagström, A., Azam, F., Anderson, A., Wikner, J., Rassoulzadegan, F. (1988). Microbial loop in an oligotrophic pelagic marine ecosystem: possible roles of cyanobacteria and nanoflagellates in the organic fluxes. Mar. Ecol. Prog. Ser. 49: 171-178

Hanson, R. B., Robertson, C. Y (1988). Spring recycling rates of ammonium in turbid continental shelf waters of the southeastern United States. Cont. Shelf Res. 8: 49-68

Harrison, W. G., Wood, L. J. E. (1988). Inorganic nitrogen uptake by marine picoplankton; evidence for size partitioning. Limnol. Oceanogr. 33: 468-475

Holligan, P. M., Harris, R. P., Newell, R. C., Harbour, D. S. Head, R. N., Linley, E. A. S., Lucas, M. I., Tranter, P. R. G. Weekley, C. M. (1984). Vertical distribution and partitioning of organic carbon in mixed, frontal, and stratified waters of the English Channel. Mar, Ecol. Prog. Ser. 14 $111-127$

Holm-Hansen, O., Strickland, J. D. H., Williams, P. M. (1966). A detailed analysis of biologically important substances in a profile off southern California. Limnol. Oceanogr. 11. $510-519$

Hopkinson, C. S., Sherr, B., Wiebe, W. J. (1989). Size fractionated metabolism of coastal microbial plankton. Mar. Ecol. Prog. Ser. 51: 155-166

Iturriaga, R., Zsolnay, A. (1983). Heterotrophic uptake and transformation of phytoplankton extracellular products. Botanica mar. 26: 375-381

Joiris, C., Billen, G., Lancelot, C., Daro, M. H., Mommaerts, J. P., Bertels, A., Bassicart, M., Nijs, J. (1982). A budget of carbon cycling in the Belgian coast: relative roles of zooplankton, bacterioplankton and benthos in the utilization of primary production. Neth. J. Sea Res. 16: 260-275

Jonas, R. B., Tuttle, J. H. (1990). Bacterioplankton and organic carbon dynamics in the lower mesohaline Chesapeake Bay. Appl. environ. Microbiol. 56: 747-757

Jumars, P. A., Penry, D. L., Baross, J. A., Perry, M. J., Frost, B. W. (1989). Closing the microbial loop: dissolved carbon pathway to heterotrophic bacteria from incomplete ingestion, digestion, and absorption in animals. Deep Sea Res 36: $483-495$

Kiørboe, T., Kaas, H., Kruse, B., Møhlenberg, F., Tiselius, P., Extebjerg, G. (1990). The structure of the pelagic food 
web in relation to water column structure in the Skagerrak. Mar. Ecol. Prog. Ser. 59: 19-32

Kirchman, D. L. (1990). Limitation of bacterial growth by dissolved organic matter in the subarctic Pacific. Mar. Ecol. Prog. Ser. 62: 47-54

Kirchman, D., Ducklow, H., Mitchell, R. (1982). Estimates of bacterial growth from changes in uptake rates and biomass. Appl. environ. Microbiol. 44: 1296-1309

Kirchman, D. L., Hoch, M. P. (1988). Bacterial production in the Delaware Bay estuary estimated from thymidine and leucine incorporation rates. Mar Ecol. Prog. Ser. 45: $169-178$

Kuosa, H., Kivi, K. (1989). Bacteria and heterotrophic flagellates in the pelagic carbon cycle in the northern Baltic Sea. Mar. Ecol. Prog. Ser. 53: 93-100

Laanbroek, H. J., Verplanke, J. C., de Visscher, P. R. M., de Vuyst, R. (1985). Distribution of phyto- and bacterioplankton growth and biomass parameters, dissolved inorganic nutrients and free amino acids during a spring bloom in the Oosterschelde basin, the Netherlands. Mar. Ecol. Prog. Ser. 25: 1-11

Lancelot, C., Billen, G. (1984). Activity of heterotrophic bacteria and its coupling to primary production during the spring phytoplankton bloom in the southern bight of the North Sea. Limnol. Oceanogr. 29: 721-730

Larsson, U., Hagström, A. (1982). Fractionated phytoplankton production, exudate release, and bacterial production in a Baltic eutrophication gradient. Mar. Biol. 67: 57-70

Lee, S., Fuhrman, J. A. (1987). Relationships between biovolume and biomass of naturally derived marine bacterioplankton. Appl. environ. Microbiol. 53: 1298-1303

Legendre, L. (1981). Hydrodynamic control of marine phytoplankton production: the paradox of stability. In: Nihoul J. C. J. (ed.) Ecohydrodynamics. Proc. 12th int. Liege Colloquium on ocean hydrodynamics. Elsevier, Amsterdam. p. 191-207

Linley, E. A. S., Newell, R. C., Lucas, M. I. (1983). Quantitative relationships between phytoplankton, bacteria and heterotrophic microflagellates in shelf waters. Mar. Ecol Prog. Ser. 12:77-89

Litaker, W., Duke, C. S., Kenney, B. E., Ramus, J. (1988). Diel chl $a$ and phaeopigment cycles in a shallow tidal estuary: potential role of microzooplankton grazing. Mar. Ecol Prog. Ser 47: 259-270

Malone, T C., Crocker, L. H., Pike, S. E., Wendler, B. W (1988). Influences of river flow on the dynamics of phytoplankton production in a partially stratified estuary. Mar. Ecol. Prog. Ser. 47: 235-249

Malone, T. C., Kemp, W. M., Ducklow, H. W., Boynton, W. R., Tuttle, J. H., Jonas, R. B. (1986). Lateral variation in the production and fate of phytoplankton on a partially stratified estuary, Mar. Ecol. Prog. Ser. 32: 149-160

McManus, G. B., Fuhrman, J. A. (1988). Control of marine bacterioplankton populations: measurement and significance of grazing. Hydrobiologia 159: 51-62

McManus, G. B., Peterson, W. T (1988). Bacterioplankton production in the nearshore zone during upwelling off central Chile. Mar. Ecol. Prog. Ser. 43: 11-17

Morris, I., Glover, H. (1981). Physiology of photosynthesis by marine coccoid cyanobacteria - some ecological implications. Limnol. Oceanogr. 26: 957-961

Newell, R. C., Linley, E. A. S. (1984). Significance of microheterotrophs in the decomposition of phytoplankton: estimates of carbon and nitrogen flow based on the biomass of plankton communities. Mar. Ecol. Prog. Ser. 16: 105-119

Ogura, N. (1975). Further studies on decomposition of dissolved organic matter in coastal seawater. Mar. Biol. 31. 101-111
Palumbo, A. V., Ferguson, R. L. (1978). Distribution of suspended bacteria in the Newport River estuary, North Carolina. Estuar. coast. mar. Sci. 7: 521-529

Patterson, R. (1973). Automated Pregl-Dumas technique for determining total carbon, hydrogen, and nitrogen in atmospheric aerosols. Analyt. Chem. 45: 211-222

Price, N. M., Cochlan, W. P., Harrison, P. J (1985). Time course of uptake of inorganic and organic nitrogen by phytoplankton in the Strait of Georgia: comparison of frontal and stratified communities. Mar. Ecol. Prog. Ser. 27: $39-53$

Ray, R. T., Haas, L. W., Sieracki, M. E. (1988). Autotrophic picoplankton dynamics in a Chesapeake Bay subestuary Mar. Ecol. Prog. Ser. 52: 273-285

Rublee, P. A., Merkel, S. M., Faust, M. A., Miklas, J. (1984). Distribution and activity of bacteria in the headwaters of the Rhode River estuary, Maryland, USA. Microb. Ecol. 10: 243-255

Ruzecki, E. P., Welch, C. S. (1979). Mid-Atlantic outer continental shelf environmental studies, Vol. II, Physical oceanography and climatology, Chap. 3. Contract no AA550-CT6-62 with the Bureau of Land Management, U.S. Department of Interior. Virginia Institute of Marine Science, Gloucester Pt.

Sanders, R. W., Caron, D. A., Berninger, U. (1992). Relationships between bacteria and heterotrophic nanoplankton in marine and fresh waters: an inter-ecosystem comparison. Mar. Ecol. Prog. Ser. 86: 1-14

Sherr, B. F., Sherr, E. B., Pedros-Alio, C. (1989). Simultaneous measurement of bacterioplankton production and protozoan bactivory in estuarine water. Mar. Ecol. Prog. Ser. 54 $209-219$

Sherr, E. B., Sherr, B. F. (1977). High rates of consumption of bacteria by pelagic ciliates. Nature 325:710-711

Sibbald, M. J., Albright, L. J., Sibbald, P. R. (1987). Chemosensory responses of heterotrophic flagellates to bacteria and several nitrogen compounds. Mar. Ecol. Prog. Ser. 36: 201-204

Stone, L. (1990). Phytoplankton-bacteria-protozoa interactions: a qualitative model portraying indirect effects. Mar. Ecol. Prog. Ser. 64: 137-145

Taylor, G. T., Iturriaga, R., Sullivan, C. W. (1985). Interactions of bactivorous grazers and bacteria with dissolved organic matter. Mar. Ecol. Prog. Ser. 23: 129-141

Torréton, J. P., Guiral, D., A.rfi, R. (1989). Bacterioplankton biomass and production during destratification in a monomictic eutrophic bay of a tropical lagoon. Mar. Ecol. Prog. Ser. 57: 53-67

U.S. Environmental Protection Agency (1979). Methods for chemical analysis of water and wastes. EPA-600/4-79-020. Office of Research and Development, Cincinnati, $\mathrm{OH}$

Webb, K. L., D'Elia, C. F. (1980). Nutrient and oxygen redistribution during a spring neap tidal cycle in a temperate estuary. Science 207: 983-985

Weisse, T. Scheffel-Møser, U. (1991). Uncoupling the microbial loop: growth and grazing loss rates of bacteria and heterotrophic nanoflagellates in the North Atlantic. Mar. Ecol. Prog. Ser. 71: 195-205

Welschmeyer, N. A., Lorenzen, C. J. (1985). Role of herbivory in controlling phytoplankton abundance: annual pigment budget for a temperate marine fjord. Mar Biol. 90: $75-86$

Wetzel, R. L. (1983). Structural and functional aspects of the ecology of submerged aquatic macrophyte communities in the lower Chesapeake Bay. Final report no. 267, U.S. Environmental Protection Agency, Chesapeake Bay Program, Annapolis, MD 
Wheeler, P. A., Kirchman, D. L. (1986). Utilization of inorganic nitrogen by bacteria in marine systems. Limnol. Oceanogr. 31. $998-1009$

Williams, P. J. leB. (1981). Bacterial production in the marine food chain: the emperor's new suit of clothes? In: Fasham, M. J. R. (ed.) Flows of energy and material in marine ecosystems. Plenum Press, New York, p. 271-300

Wright, R. T (1988). A model for short term control of the bacterioplankton by substrate and grazing. Hydrobiologia 159: $111-117$

Wright, R. T., Coffin, R. B. (1983a). Planktonic bacteria in estu-

This article was submitted to the editor aries and coastal waters of northerm Massachusetts: spatial and temporal distribution. Mar. Ecol. Prog. Ser. 11: $205-216$

Wright, R. T., Coffin, R. B. (1983b). Factors affecting bacterioplankton density and productivity in salt marsh estuaries. In: Reddy, C. A., Klug, M. J. (eds.) Current perspectives in microbial ecology. Am. Soc. Microbiol., Washington, DC, p. $485-494$

Wright, R. T., Coffin, R. B. (1984). Measuring microzooplankton grazing on planktonic marine bacteria by its impact on bacterial production. Microb. Ecol. 10: 137-149

Manuscript first received: October 28, 1991

Revised version accepted: June 14, 1993 